\title{
The Implementation of Cooperative Learning Approach with Multimedia for Children's Literature Learning at Elementary School in the Characters Building Perspective
}

\author{
Rukayah $^{1}$, St. Y. Slamet ${ }^{2}$, and Andayani ${ }^{2}$ \\ ${ }^{1}$ Faculty Of Teacher Training And Education Sebelas Maret University Indonesia \\ ${ }^{2}$ Faculty Of Teacher Training And Education Sebelas Maret University Indonesia \\ Corresponding Email: rukayah.pgsd@yahoo.co.id
}

\begin{abstract}
In the 21 st century, the pre-service science teachers faced on extremely global competitiveness, globalization, technologically driven by information and rapidly media-saturated that needs apropriate skills to meet these challenges. The aims of this study is to identify pre-service science teacher perception about HOTs in $21^{\text {st }}$ century. This study employed quantitative design using a survey research method involved 120 pre-service science teachers from Tanjungpura University. The results of this study indicated that students are aware of the importance of HOTs and learning that emphasizes the aspects of HOTs to face the challenges of the 21 st century. It is indicated by the mean score of pre-service science teacher perception about the important of HOTs to meet the challenges in the 21 st century $(\mathrm{M}=4.29, \mathrm{SD}=0.61)$ and the skills of HOT that their will be required to becomes a teacher in the 21 st century $(\mathrm{M}=4.31 ; \mathrm{SD}=0.47)$ in the high level. This is also provides the reasons why we need cultivating a positive awareness of the importance of HOTs in order to fostering the need for teaching that emphasizes the aspects of HOTs during pre-service education.
\end{abstract}

Keywords: Perception, Pre-service Science Teacher, High Order Thinking Skills (HOTs), $21^{\text {st }}$ Century

DOI: $10.20961 /$ ijpte.v\%vi\%i.15798 


\section{INTRODUCTION}

The main function of literature learning in elementary school was mind smoothing, enhancing the humanity sense and social sensitivity, cultural appreciation and ideas distribution, imagination and expression with creative and constructive manner, both orally and in writing (Depdiknas, 2004). Similarly, according to Moody (1979), the literature learning was useful to establish the language skills, enrich science, supporting the development of the soul, as well as help to build the character.

In line with the above literature learning function, Oemaryati (2005: 7) states that the end purposes of literary appreciation learning are to enrich the pupils' experience and make it more responsive to the values, both in individual and social contexts. The tools to the direction are skills of listening, speaking, reading, and writing. The purposes of children's literature learning in elementary school in the curriculum are (1) to enjoy and take advantage of literary works to broaden their horizons, and refine the character, as well as increasing the knowledge and language skills; (2) respect and be proud of Indonesian literature as a cultural and intellectual repertoire of Indonesia society (Depdiknas, 2006).

The children's literature learning was very useful for elementary school students because it helps their mental development. According to Akhadiah (1992), there are at least five benefits for life when appreciating literature, namely (1) the aesthetic benefits; (2) the education benefits; (3) the inner sensitivity and social benefits; (4) add insight; and (5) the psychiatric benefits or personality development. Huck et al (1987) also argued that through interaction with literature, at least the students will get some values for their development, namely (1) the language development, (2) cognitive development, (3) the personality development, and (4) social development.

Literary work help the children understand their world, forming positive attitudes, and realize human relationships (Sawyer and Comer, 1991). Similarly, Zuhdi and Budiasih (1997) revealed that children's literature learning can develop positive attitudes among (1) awareness of self-esteem; (2) tolerance towards others; (3) curiosity about life and realize to the human relationships.

In the study of children's literature, teachers must understand the literary learning curriculum with the function, scope, standards competence / core competencies, basic competencies, indicators, subject matter, and be able used it in the lesson learning, and presents the lessons in the class. In addition, the teachers should have experience in adequate knowledge of children's literature. All of that will facilitate teachers to teach their students.

In the real practice, it is found the phenomenon that not all of elementary school teachers that tought children's literature have a great interest in children's literature and able to compose it. Therefore, it is common that the teacher teaches literature based on the mind of "the teacher must teach the literary, however they way". Such things often lead to the students that is not interested in children's literature. The main case of such problem is the less skilled teacher in select, specify, construct, and develop the learning materials and lack of control of innovative learning strategies to deliver the children's literature learning. As a 
result, children's literature learning for elementary school are not interesting and fun learning.

Another thing that was often experienced by teachers and students in Indonesian language and literature learning in the classroom is the question of how students' attentiveness and pleasure during learning (Dadan, 2006). Students ofren feel tired and bored because they must focus on training provided by the teacher. The teachers should create conducive atmosphere so the students feel happy in the learning literature. The pleasure in children's literature learning will be able to improved students' creativity and ability and found the experience and new knowledge. Thus when language and literature Indonesian learning took place, students learned in a conductive condition and not boring.

Based on observations at several schools in children's literature learning actitivies, various problems encountered. Some problems related to the teachers' competency in explaining the material of children's literature learning, for example, requited rhyme, only implemented by reading the rhymes reciprocated. In the rhymes writing, teacher did not explaine the steps.

Another finding is about the learning procedure of children's literature. In some schools, it turns out that teachers use "teacher centered", not "student-centered" learning method. Teachers teach without prior dialogue with the students, so it appears that the teacher is the only as a source, as well as learning interaction is only one direction from the teacher to the student.

Based on that, then the learning implementation necessary to have multidirectional interaction, which is an effective interaction. Interaction between teachers with students, students with teachers, and students with students is an important way in sustainability study. This is in line with the opinion of De Potter (2005) that the interaction between teachers and students, students with students is a process that converts light into energy that causes the learning process interesting and fun for students. Energy here in the mean of the method, learning infrastructure that caused the learning situation becomes conducive to developing students.

To improve the learning process in order to be conducive to the development of the student it is necessary to use the right approach and strategy. One of the popular approaches is cooperative learning approach. Cooperative learning aims to increase academic cooperation between students, forming positive relationships, develop self-confidence, and improve academic skills through group activities (Asri Budi Ningsih, 2008). Similarly, according to Lie (2005) the cooperative learning, in its activities, each member of the group gets a chance to give their contribution and listen the views and ideas of others students. So one of the advantages of cooperative learning is to overcome barriers, to give equal opportunities so there are not dominant members in the group.

The literature learned in elementary school is essentially a children's literature, because in addition to containing the characteristics of a wide range of children's literature, there remains a marked characteristic of children's literature is different from the adult literature. Sarumpaet (1976) suggested three characteristics distinguishing, namely (1) the abstinence elements; (2) direct presentation style; 
and (3) the applied function. Children's literature to avoid problems related to the problem of sex, erotic love, revenge that cause hatred, cruelty, prejudice, deception evil, and death issue.

The used cooperative learning approach with multimedia in the children's literature learning in elementary school with some consideration, includes of the basis of cooperative learning itself is working together will produce the so-called collective energy (synergy). This synergy will produce something extraordinary. This synergy in education applied in communities learning (Johnson \& Johnson, 1994; Slavin, 1995; Joyce, 2009). In addition, cooperative learning arises because of an assumption basic nature of man as a social being, as well as their ways to learn.

In this study, cooperative learning that applied are STAD (Student Team Achievement Devition), Jigsaw, CIRC (Cooperative Integrated Reading and Composition), and TGT (Team Games Tournament). The implementation of the four types of cooperative learning in this study because according to the children's literature learning materials in elementary school. The multimedia using is appropriated to the learning material. The using of correct multimedia will easier the children's literature learning.

Based on the above descriptions, the children's literature learning in elementary school would be more feasible if presented with a cooperative approach and literary study were receptive and productive. Therefore, the children's literature learning models in elementary school and cooperative approach based on the existing curriculum needs to be investigated.

Based on the problem background, the problem in this research can be formulated as follows: 1) How is the effectiveness of cooperative learning approach with multimedia for children's literature learning at elementary school?; and 2) How the acceptability of cooperative learning approach with multimedia for children's literature learning at elementary school based on the stakeholders' opinion?

The objectives of this study were: 1) Finding the effectiveness of the cooperative learning approach with multimedia for children's literature learning at elementary school; and 2) Describe the acceptability of cooperative learning approach with multimedia for children's literature learning at elementary school based on the stakeholders' opinions.

\section{METHODS}

This research is conducted in two stages (1) experiment stage; and (2) dissemination stage. The experiment used in this research is quasi experiment. This research used the research approach formulated by Borg and Gall (2003).

The subjects of this research were students and teachers of fourth and fifth grade of elementary school in two districts Grobogan and Purworejo Central Java Indonesia. Multistage sampling is used as the sampling technique with total samples of 161 students. The data sources this study includes (1) the informant, the students and teachers of fourth and fifth grade of elementary school, principal, and superintendent of schools; (2) events, namely the children's 
literature learning activities in fourth and fifth grade of elementary school where studied; (3) the document, in the form of syllabi, lesson plans, and other relevant documents; and (4) test results.

Observation, field recording and testing are three data collection techniques that is used in this research. The data validity testing used the correlation point biserial and reliability data was used KR-20 (Kuden-Richardson-20) formula. The qualitative data in this study were analyzed by using interactive analysis (Miles and Huberman, 2007), which consists of three flow analysis activities, namely data reduction, data presentation, and conclusion. The data were analyzed with quantitative statistical test with one way ANOVA, while the test requirements include homogeneity test with Levine's test techniques and normality test with Kolomogorov-Smirnov Test techniques. It was all done with the help of a computer, using SPSS.

\section{RESULT AND DISCUSSION}

\section{The Effectiveness of Cooperative Learning Approach with Multimedia}

To determine the effectiveness of cooperative learning approach with multimedia for children's literature learning, quasi experiments was conducted in two districts of Grobogan and Purworejo Central Java Indonesia. Before this experiments carried out, both the experimental and control groups were given the pretests of children's literature. After experiment, the experimental and control groups were given post-test. The children's literature test results from fourth and fifth grades of elementary school can be seen in Table 1 and 2 respectively.

Table 1 The children's literature test results of Fourth Grades of Elementary School

\begin{tabular}{crrrccc}
\hline No. & Group & $\mathrm{N}$ & Highest Value & Lowest Value & Mean & $\begin{array}{c}\text { Standard } \\
\text { Deviation }\end{array}$ \\
\hline 1 & A1 & 81 & 18 & 9 & 13.7531 & 2.23903 \\
2 & A2 & 81 & 20 & 12 & 16.3210 & 2.07260 \\
3 & B1 & 81 & 17 & 7 & 13.1605 & 2.57612 \\
4 & B2 & 81 & 19 & 10 & 14.7654 & 2.13466 \\
\hline & $\mathrm{A}_{1}$ & $:$ & Experiment group before experiment implementation \\
& $\mathrm{A}_{2}$ & $:$ & Experiment group after experiment implementation & \\
& $\mathrm{B}_{1}$ & $:$ & Control group before research implementation & \\
& $\mathrm{B}_{2}$ & $:$ & Control group after research implementation
\end{tabular}

Table 2 The children's literature test results of fifth grade of Elementary School

\begin{tabular}{crrrccc}
\hline No. & Group & $\mathrm{N}$ & Highest Value Lowest Value & Mean & $\begin{array}{c}\text { Standard } \\
\text { Deviation }\end{array}$ \\
\hline 1 & $\mathrm{~A} 1$ & 80 & 22 & 12 & 16.4500 & 2.92480 \\
2 & $\mathrm{~A} 2$ & 80 & 24 & 15 & 18.9875 & 2.85734 \\
3 & $\mathrm{~B} 1$ & 80 & 20 & 10 & 15.7250 & 2.90340 \\
4 & $\mathrm{~B} 2$ & 80 & 23 & 13 & 17.4500 & 2.90743 \\
\hline & $\mathrm{A}_{1}$ & $:$ & Experiment group before experiment implementation \\
& $\mathrm{A}_{2}$ & $:$ & Experiment group after experiment implementation \\
& $\mathrm{B}_{1}$ & $:$ & Control group before research implementation & \\
& $\mathrm{B}_{2}$ & $:$ & Control group after research implementation
\end{tabular}


Based on the above table it is clear that the average value between before and after treatment, both in the experimental and control groups are differ. However it turned out that the experiment group with cooperative learning approch with multimedia is relatively better when compared with control group.

Normality test results obtained Asymp Sig value greater than $\alpha$ of 0.05 for both in fourth and fifth grades of elementary school. Thus, it means that the sample comes from a population group that is normally distributed. The homogeneity test results, obtained the Sig value greater than $\alpha=0.05$. Which meacn that the variant of population data are homogene.

The ANOVA test results from fourth and fifth grades of elementary school can be seen in Table 3 and 4 respectively

Tabel 3 The Anova Tets Result of Fourth Grade of Elementary School

\begin{tabular}{cccccccc}
\hline No & Group & $\begin{array}{c}\text { Sum of } \\
\text { Squares }\end{array}$ & df & $\begin{array}{c}\text { Mean } \\
\text { Squares }\end{array}$ & $\mathrm{F}_{\text {count }}$ & $\mathrm{F}_{\text {table }}$ & $\mathrm{P}$ \\
\hline 1 & I & 14.222 & 1 & 14.222 & 2.442 & 3.91 & $<0.05$ \\
2 & II & 98.000 & 1 & 98.000 & 22.141 & 3.91 & $>0.05$ \\
3 & III & 267.062 & 1 & 267.062 & 57.377 & 3.91 & $>0.05$ \\
4 & IV & 104.321 & 1 & 104.321 & 18.640 & 3.91 & $>0.05$ \\
\hline
\end{tabular}

Tabel 4 The Anova Tets Result of Fifth Grade of Elementary School

\begin{tabular}{cccccccc}
\hline No & Group & $\begin{array}{c}\text { Sum of } \\
\text { Squares }\end{array}$ & df & $\begin{array}{c}\text { Mean } \\
\text { Squares }\end{array}$ & $\mathrm{F}_{\text {count }}$ & $\mathrm{F}_{\text {table }}$ & $\mathrm{P}$ \\
\hline 1 & I & 21.025 & 1 & 21.025 & 2.476 & 3.91 & $<0.05$ \\
2 & II & 94.556 & 1 & 94.556 & 11.380 & 3.91 & $>0.05$ \\
3 & III & 257.556 & 1 & 257.556 & 30.810 & 3.91 & $>0.05$ \\
4 & IV & 119.025 & 1 & 119.025 & 14.100 & 3.91 & $>0.05$ \\
\hline I & $\begin{array}{l}\text { The comparison of children's literature value of experimental and control group before } \\
\text { experiment. }\end{array}$ \\
II & $\begin{array}{l}\text { The comparison of children's literature value of experimental and control group after } \\
\text { experiment. }\end{array}$ \\
III & $\begin{array}{l}\text { The comparison of children's literature value of experimental group before and after } \\
\text { experiment. }\end{array}$ \\
IV & : The comparison of children's literature value of control group before and after experiment.
\end{tabular}

Based on the above table, the ANOVA test on fourth grade between the experimental group before and after the experiment obtained a value of 57.377; whereas in the control group of 18.640 with a confidence level of less than at $\alpha=$ 0.05 . This means that cooperative learning approch with multimedia can improve children's literature achievements. The ANOVA test results between the experimental and control group after experiment is 22.141 with confidence level is smaller than 0.05. In addition, the average value of $16.3210>14.7654$. Because of these differences mean that there is a significant effect of the implementation of cooperative learning on the children's literature achievement of fourth grade of elementary school.

Likewise, the ANOVA test results on fifth grade between the experimental group before and after the experiment obtained a value of 30.810 , while the control 
group of 14,100 with a confidence level of less than 0.05 . This means that cooperative learning approach with multimedia can improve children's literature. The results of the ANOVA test between the experimental and control group after both getting treatment is 11.380 with a confidence level of 0.05 . In addition, the average value of 18.9875> 17.4500. Because of these differences mean that there is a significant effect of the implementation of cooperative learning on the children's literature ability of class V elementary school.

\section{Dissemination and Acceptance of Cooperative Learning Approach with Multimedia Implementation}

The dissemination of this research product with published the book of "Guidelines of Children's Literature Learning with Cooperative Learning Approach in Elementary school" with the ISBN No. 978-979-498-719-3. To determine the acceptability of the cooperative learning approach with multimedia, the researchers got a response from various parties is secondary school supervisor, head and teachers of elementary school. Based on the responses obtained can be said that the children's literature learning that was experimented in this study can be received well.

\section{Discussion}

Based on the above results can be disclosed following discussion. Based on the effectiveness test results, it was shown that the children's literature learning with cooperative learning approach in elementary school looks any meaningful progress. It is evident from the comparison of pretest scores with post-test scores after children's literature learning with cooperative learning approach with multimedia better than conventional one. In addition, also the comparison of posttest scores between children's literature learning with cooperative approach and conventional approach (teacher oriented). From the children's literature ability, students who follow the teaching of children's literature with a cooperative approach performed better than the students who follow the teaching of children's literature with the conventional approach. The difference was significant, indicating that the implementation of cooperative learning approach on the children's literature learning was more effective than conventional learning in elementary school.

The results of this study support the study of Andayani (2008) with the result that students' competence were taught the children's literature appreciation with the social model patterned group investigation better than the role playing model. Likewise, according to the study results by Dyah Sulityowati (2011) which proven that the students' writing ability who follow the writing learning with CIRC approach better than granting duty method. Thus, the appropriate children's literature learning method can affect the ability of children's literature students.

Significant advances in the children's literature learning with cooperative learning approach with multimedia in elementary school in this study viewed from the comparison of pretest and posttest scores after children's literature learning used cooperative learning approach with multimedia. In addition, the students' 
children's literature ability used cooperative learning approach with multimedia better than children's literature learning with conventional learning. The significant difference, indicating that the implementation of cooperative learning approach with multimedia in the children's literature learning more effective than children's literature learning with conventional learning in elementary school.

Teachers' responses to the children's literature learning used cooperative learning approach with multimedia in elementary school are positive. The positive response indicates that the development of children's literature learning model used cooperative learning approach with multimedia in elementary school was grateful. The acceptance of cooperative learning approach with multimedia in the children's literature learning will lead to the expectation that the children's literature learning in the future will better than the current practice.

In addition, the teacher's acceptance for children's literature learning model used cooperative learning approach with multimedia in elementary school, also useful for teachers, because teachers can feel more confident in applying one of the innovative learning, so that teachers will be able to develop their skills. Likewise, the response from the Principal and Supervisor that by publishing the book of "Guidelines of Children's Literature Learning with Cooperative Learning Approach in Elementary school" can facilitated teachers in planning, implementing, and evaluating learning in elementary school, especially in the children's literature learning. By which, it can improve the quality of teacher's elementary school profession.

\section{CONCLUSION}

Based on the study results and discussion, the experimental research of children's literature learning models with cooperative approach in elementary school can be summarized as follows: 1) The cooperative learning more effective than the conventional learning; and 2) Acceptance of children's literature learning model with cooperative approach in elementary school in this study as well as a dissemination stage are as the socialization of the final product in the form of "Guidelines of Children's Literature Learning with Cooperative Learning Approach in Elementary school".

Based on the study results and the conclusions, several recommendation can be given. (1) The elementary school teachers, especially in language and literature of Indonesia learning are expected not to leave children's literature as learning materials. Children's literature must be taken as learning material should be close to and in accordance with the students' everyday life (seen, heard, experienced, felt, and things happen or exist around students). (2) The elementary school teachers in children's literature learning should integrate several aspects of language skills such as good listening, speaking, reading, and writing, which will give more opportunities for students to explore, elaborate, and appreciate. (3) Policy makers in elementary school, was expected to play a role as well as to overcome the problems faced by teachers, by organizing and facilitating collaboration of elementary school managements with stakeholders and universities in the form of supervision of the preparation of lesson plans, implementation of innovative learning, and development of learning assessment 
in children's literature. (4) In future research deeper and wider assessment muct be conducted using different approach and methods by involving other factors that influence the children's success in the literature learning. Not only done by uses different approaches and methods, but also involved other factors that supposed to influence the children's success in learning literature.

\section{REFERENCES}

Akhadiah, Sabarti. 1992. Bahasa Indonesia. Jakarta: Depdikbud Dirjen Dikti.

Borg, Wlater R, Gall, Goyce P, Gall Meedith D. 2003. Educational Research: An Introduction. Seventh Edition. Boston: Pearson Education.

De Poter, Bobbi. 2005. Quantum Teaching, Mempraktikkan Quantum Learning (Terjemahan Ary Nilandari). Bandung: Kaifa.

Depdiknas. 2006. Pelaksanaan Kurikulum untuk Tingkat Satuan Pendidikan Dasar. Jakarta: Pusat Pengembangan Kurikulum. Balitbang.

Djuanda, Dadan. 2006. Pembelajaran Bahasa Indonesia yang Komunikatif dan Menyenangkan. Jakarta: Depdiknas. Dirjen Dikti.

Grosjean, Francois. 2004. Testing for Language-Art. Cambridge: Cambridge University Press.

Huck, Charlotte S; Hepler Susan; Hickman Janet. 1987. Children's Literature in the Elementary School. Fourth Edition. New York: Holt, Rinehart and Winston, Inc.

Iser, Wolfgang. 1978. The Act of Reading. London: Routledge \& Kegan Paul.

Isjoni. 2009. Cooperative Learning Mengembangan Kemampuan Belajar Berkelompok. Bandung: Alfabeta.

Johnson, RT \& DW Johson. 1994. An Overview of Cooperative Learning” dalam J. Thousand A Villa dan A. Neven (Ed). Creativity and Collaborative Learning. Baltimore: Brookes Press.

Johnson, RT \& DW Johson. 2006. What is Cooperatie Learning? Minneapolis, Minnesota: The Cooperative Learning Center at the University of Minnesota

Joyce, Bruce; Marsha Whil, \& Emily Cahoun. 2009. Models of Teaching. New Jersey: Prentice Hall Inc.

Kemendikbud. 2013. Kerangka Dasar dan Stuktur Kurikulum Sekolah Dasar/Madrasah Ibtidaiyah. Jakarta: Kemendikbud.

Lie, Anita. 2008. Coopeartive Learning, Mempraktikkan Cooperative Learning di Ruang Kelas. Jakarta: Grasindo.

Long, Martyn. 2000. The Psychology of Education. Routledge: Routledge Falmer Publishing.

Miles, Matthew B. Huberman A. Michael. 2007. Analisis Data Kualitatif. Terjemahan Tjetjep Rohendi Rohidi. Jakarta: Penerbit Universitas Indonesia (UI Press). 
Moody, H.L.B. 1979. The Teaching of Literature: With Special Reference to Developing Countries. London: Longman Group, Ltd

Ningsih, Asri Budi. 2008. Model-model Pembelajaran Inovatif dan Partisipatif. Surakarta: Pusat Pengembangan Sistem Pembelajaran. LPP UNS.

Oemaryati, Boen S.. 2005. Pengajaran Sastra pada Pendidikan di Indonesia. Duo Vadis (Dalam Index Asp? Act detail Indrec: 213). Diunduh 20 April 2009

Richards, J.C. \& Theodore S. Rodgers. 2001. Approachers and Methods in Language Teaching. Cambridge: Cambridge University Press.

Sawyer, Walter dan Comer, Diana F. 1991. Growing Up With Literature. Albany. New York: Delmal Publisher Inc.

Slavin, Robert, E. 1995. Cooperative Learning. Boston, London, Toronto, Syney Tokyo, Singapore: Allyn and Bacon Inc.

Slavin, Robert, E. 2008. Cooperative Learning: Teori Riset dan Praktik (Terjemahan Nurulita). Bandung: Nusa Media.

Sugiyono. 2008. Metode Penelitian Pendidikan: Pendekatan Kuantitatif, Kualitatif, dan R \& D. Bandung: Alfabeta

Sukmadinata, Nana Syaodih. 2008. Metode Penelitian Pendidikan. Bandung: PT. Remaja Rosdakarya.

Zuhdi, Darmiyati dan Budiasih. 1996/1997. Pendidikan Bahasa dan Sastra Indonesia di Kelas Rendah. Jakarta: Depdikbud. 